Article

\title{
Food Values, Benefits and Their Influence on Attitudes and Purchase Intention: Evidence Obtained at Fast-Food Hamburger Restaurants
}

\author{
Héctor Hugo Pérez-Villarreal ${ }^{1, *(1)}$, María Pilar Martínez-Ruiz ${ }^{2}$, Alicia Izquierdo-Yusta ${ }^{3}$ and \\ Carmen María Gómez-Cantó ${ }^{2}$ \\ 1 Faculty of Marketing, UPAEP University, Puebla 72410, Mexico \\ 2 School of Economics and Business Sciences, University of Castilla-La Mancha, 02071 Albacete, Spain; \\ MariaPilar.Martinez@uclm.es (M.P.M.-R.); CarmenMaria.Gomez@uclm.es (C.M.G.-C.) \\ 3 School of Economics and Business Sciences, University of Burgos, 09001 Burgos, Spain; aliciaiz@ubu.es \\ * Correspondence: hectorhugo.perez@upaep.mx
}

Received: 29 August 2020; Accepted: 15 September 2020; Published: 19 September 2020

check for updates

\begin{abstract}
This paper analyzes the effects of: (i) Food values on their related benefits (hedonic and utilitarian); (ii) both kinds of benefits on attitudes toward eating hamburgers; and (iii) attitudes on purchase intention. To this end, we adapted the food values scale to the context of fast-food hamburger restaurants. Data were collected from a survey of 512 Mexican consumers and analyzed using structural equation modeling (SEM). The results show that the strongest influences are those exerted by food values, first, on hedonic benefits and, second, on utilitarian benefits. In contrast, the weakest influence is that exerted by utilitarian benefits on attitudes, followed by that exerted by hedonic benefits on attitudes. Among other findings, this study highlights the importance consumers give to the taste and safety of food, as well as the greater importance given to hedonic benefits compared to utilitarian ones. These findings have several important implications for managers in the industry.
\end{abstract}

Keywords: food values; hedonic benefits; utilitarian benefits; attitudes toward eating hamburgers; purchase intention

\section{Introduction}

In recent years, both academics and managers have taken a special interest in exploring consumer behavior in terms of the food decision-making process. This interest encompasses a few different phenomena: From an academic perspective, some studies (e.g., Barahona et al.) [1] have observed a growing attention to food in the marketing discipline, particularly in the fields of consumer choice and marketing channel management. The literature is also devoting greater attention to relatively new concepts such as food values by analyzing their role in food purchasing and consumption processes [2-4]. These efforts speak to a broader attempt at understanding and forging bonds with consumers, as reflected in marketing approaches such as Marketing 3.0 and Marketing 4.0 [4].

Meanwhile, from a managerial perspective, companies in the food industry recognize that success in today's competitive food markets begins with understanding how product attributes influence consumers' food decision-making processes [5,6]. As Grunert (2011) [7] suggests, developing an understanding of consumers-and particularly how to manage relationships with them-can be a key competitive advantage for food companies. Unsurprisingly, then, many companies are trying to devise strategies to better understand consumers' purchasing behaviors.

In this regard, it is important to consider that consumers' food choices are more complex than ever before, which has made it all the more difficult to understand and predict such behavior [8]. 
Many studies have tried to identify consumer preferences for specific product attributes, without taking into account the wide range of products at consumers' disposal that are characterized by an even wider variety of attributes [9]. For this reason, Lusk and Briggeman (2009) [3] studied the general classifications of food values, which express more abstract attributes that can explain consumer purchases over time. These food values often encompass numerous physical attributes simultaneously and may be responsible for consumers preferring one product over another [2,3].

However, a product's associated food values can differ from the benefits it confers to consumers. These benefits can substantially influence subsequent marketing outcomes such as satisfaction, repeat purchases, recommendations, etc. $[10,11]$. In order to satisfy their needs, consumers emphasize values that provide certain benefits related to pleasure, utility, or, in some cases both [12]. The relevant literature has traditionally considered benefits in terms of a product's attributes. For example, Chitturi et al. (2008) [13] categorized said benefits as hedonic and utilitarian, while Crowley et al. (1992) [14] noted that these benefits can be high or low depending on the product. Consistent with work done by Chitturi et al. (2008) [13], this research distinguishes between the hedonic and utilitarian benefits associated with food values.

Another variable to consider in the food decision-making process is consumers' attitude. In general, people's attitude toward consuming a product stems from their perceptions of the object's attributes or characteristics $[15,16]$. Because attitudes influence behavior, they can help to explain consumers' food choices. Furthermore, attitude influences consumers' intention, which is an intermediate step between attitude and behavior. Intentions reflect a person's decision to perform a certain behavior, which will only be taken when the person has total control over the behavior [17].

Building on these ideas, the present paper analyzes the decision-making process behind the consumption of a specific type of fast food (hamburgers) at a particular kind of restaurant (fast-food restaurants). Specifically, this study aims to examine the influence of: (i) Food values on their related benefits (hedonic and utilitarian); (ii) both kinds of benefits on attitudes toward eating hamburgers; and (iii) these attitudes on purchase intention. To this end, we will first review the relevant literature on food values, related benefits (hedonic and utilitarian), attitudes toward eating hamburgers, and purchase intention, which will allow us to propose the research hypotheses. We will then describe the empirical research conducted to test the hypotheses. Finally, we will derive the main findings and highlight the key managerial implications.

\section{Conceptual Framework}

In this section, we will present the conceptual framework, which will enable us to hypothesize a series of key relationships between the variables. In the field of food, one of researchers' major tasks has been to explain food consumption behavior [18]. Among the diverse theories advanced for such purposes [19], Ajzen's (1991) [20] theory of planned behavior (hereafter, TPB) has attracted broad application and empirical support in several domains, such as the intention to eat pizza, snacks, genetically modified food, meat, beer, a low-fat diet or healthy foods (e.g., Louis et al., 2007; Tuu et al., 2008) [18,21]. This theory originates within the expectancy-value tradition of attitude-behavior research, and offers a simple, parsimonious model [22]. In recent years, scholars have suggested several extensions and modifications to this theory to improve its predictive and exploratory power [18,23-25]. Against this background, we will adopt this theoretical framework to assess the intention to purchase a certain kind of food (i.e., hamburgers). Importantly, we will utilize attitude toward consuming this food, as well as food values and their related benefits, as predictors of people's intentions.

\subsection{Food Values and Related Benefits}

Traditionally, the scientific community has shown great interest in the relationship between individuals and their food purchase decisions. Today's consumers face a complex environment for food choices; thus, understanding and predicting the choice process has become a difficult task [26]. Some have even claimed that consumers act irrationally or even randomly when choosing food products [8]. 
However, it may be more accurate to say that consumers have developed more dynamic, complex and differentiated demands, and thus their food choices are influenced by multiple aspects [8].

However, consumers assign different importance to the attributes of a given food product [27]. Many studies have tried to identify consumer preferences for specific product attributes, but this task is confounded by the fact that consumers have a wide range of products at their disposal, which feature an even wider variety of attributes or characteristics [9]. For this reason, Lusk and Briggeman (2009) [3] studied the general classifications of food in the form of food values, which express more abstract attributes that can explain consumer purchases over time. In this sense, consumers base their product choices on a set of inferred food values, which often encompass numerous physical attributes simultaneously [3]. Specifically, Lusk and Briggeman (2009) [3] identified the food values of naturalness, taste, price, safety, convenience, nutrition, origin, fairness, tradition, appearance, and environmental impact. Lusk (2011) [2] adopted these same values, but later researchers added others such as animal welfare or novelty (see for instance, Bazzani et al., 2018) [28]. In recent years, these food values were connecting to others directions as post-purchase, loyalty, satisfaction, emotions, motivations, attitudes, and others [25,29-31]. Thus, the only purpose is enhancing the relationship between food values and decision-making choice.

Likewise, some research (e.g., Izquierdo-Yusta et al., 2019) [32] has focused on segmenting consumers according to food values. In this vein, these authors identified three groups of consumers: 1) Mainly utilitarian, focusing on food values such as price; 2) mainly hedonic, focusing on food values such as taste; and 3) mainly ethical, focusing on values such as environmental impact. Put differently, consumers pursue food products on the basis of some objective(s), which are reflected in the benefits that consumers perceive in the product. Along this line, Batra and Ahtola (1991) [33] suggested that consumers buy goods and services and perform consumption behaviors for two basic reasons: (1) Consummatory affective (hedonic) gratification (from sensory attributes), and (2) instrumental, utilitarian reasons related to achieving some result. Hedonic benefits are oriented around increasing the likelihood of a pleasant experience and, by extension, positive emotions, while utilitarian benefits are oriented around balancing functional objectives with the related sacrifices (e.g., of time, money) [33-35]. Therefore, hedonic benefits are more subjective and personal; utilitarian benefits are more geared toward achieving a task [36]. Because people generally prioritize the avoidance of harm or pain and treat pleasure as a luxury, utilitarian benefits are often emphasized over hedonic ones.

Building on this argument, Chitturi et al. (2008) [13] proposed that hedonic and utilitarian consumption fundamentally differ in the emotional experience they offer: Delight or satisfaction, respectively. These authors thus predicted that the type of positive emotional response evoked by consuming a product depends on whether the offer exceeds the expectations for hedonic or utilitarian benefits. They argued that exceeding hedonic expectations will produce a feeling of delight, while exceeding utilitarian expectations will only result in satisfaction. In contrast, failing to fulfill hedonic or utilitarian expectations would cause anger or dissatisfaction, respectively. It also seems consumers align food attributes more with hedonic or utilitarian benefits. For example, various authors (e.g., Cramer and Antonides, 2011; Khongrangjem et al., 2018; Loebnitz and Grunert, 2018; Maehle, Iversen, Hem and Otnes, 2015) [37-40] have contended that taste is more important for hedonic products, while Wakefield and Inman (2003) [41], Maehle et al. (2015) [40] and Liu et al. (2020) [42], have found that price is more important for utilitarian products.

Based on these findings, for the purposes of the present research, 'hedonic benefits' will refer to the aesthetic, experiential, and enjoyment-related benefits of food values, whereas 'utilitarian benefits' will refer to the functional, instrumental, and practical benefits of food values.

\subsection{Attitudes and Intention}

In the field of cognitive psychology, attitude is the main factor that guides and determines human behavior [43]. Appropriately, attitude is an important predictor of the intention to consume food $[18,44,45]$. 
In this regard, the Theory of Reasoned Action (hereafter, TRA) usefully encapsulates the attitude-behavior relationships that link attitudes with subjective norms, behavioral intentions and behavior in a fixed causal sequence. This theory presumes that behavior is a direct function of intention, which is itself a function of attitude and subjective norm. Moreover, a person's attitude toward performing the behavior is deemed to be a summed product of individuals' beliefs and their evaluation of said beliefs [46]. This theory underlies Ajzen's (1991) [20] TPB, in which the attitude toward the behavior reflects the degree to which a person has a favorable or unfavorable appraisal of the behavior in question. In this setup, people's beliefs about the outcome of the behavior, as well as their evaluations of these outcomes, produce an 'attitude towards the behavior [20]. TPB posits that people will be more likely to engage in a given behavior when they hold a positive attitude toward participating in said behavior.

In general, people's attitudes toward an object (in this case, a food product) result from a perceived combination of the object's attributes or characteristics [16,47]. When consumers hold a positive attitude toward a certain food product, they will be more likely to purchase said product and probably show a positive attitude toward the providing establishment. In this vein, Haws and Winterich (2013) [48] described four key aspects of people's attitude toward eating hamburgers: Pleasure, enjoyment, satisfaction, and good taste.

Any discussion of attitude should account for intention, which serves as a bridge concept between attitude and behavior. Previous studies have identified a positive predictive relationship between people's attitude toward eating and intention to buy food products [48,49]. For example, Chen (2009) [50] and Vaz et al. (2009) [51] suggested that a positive attitude galvanizes consumers' intention to purchase organic food. Likewise, Chen (2009) [50] found that people's attitudes toward eating hamburgers influences their purchase intention. In general, in the context of fast food, it has been commonly found that the attitude toward eating hamburgers is a relevant variable in behavioral intention toward purchasing [52-54].

\subsection{Hypotheses}

Building on the aforementioned idea that consumption decisions can be complex, the present study accounts for the formation of attitudes and intentions that underlie behaviors in the specific context of fast-food hamburger restaurants. In particular, following the framework of the TPB [20], it aims to assess people's intention to consume a certain kind of food (hamburgers) at fast-food restaurants, incorporating several variables as predictors (i.e., food values, their related benefits, and people's attitudes). Under this theoretical framework, food values and their associated benefits (both hedonic and utilitarian) can be posited as predictors of attitudes, which, in turn, can be considered predictors of intention.

Scholars have found that people's intention to purchase fast food largely depends on food values, their associated benefits, and attitudes. For example, preserving health and wellbeing is a key concern for many consumers; they thus want to understand the nutritional value of what they eat and strive to follow a balanced diet that lowers the risk of obesity and chronic diseases [55]. In this research line, Mattsson and Helmersson (2007) [56] concluded that Swedish high school students are generally aware of the negative side effects of fast food and accordingly pay more attention to nutritional and health concerns than to price, speed, and convenience. Yoon and Chung (2018) [57] observed that the hygienic and environmental risks of food trucks exerted a negative impact on consumers' attitudes toward the food-truck dining experience, while hedonic benefits resulted in a favorable attitude. Likewise, in their study of the factors influencing consumers' attitudes toward fast-food consumption, Ghoochani et al. (2018) [58] observed that health consciousness was one of the main factors shaping respondents' attitudes.

Many studies have tried to verify the importance of such variables on people's intention to eat fast food. For instance, Dunn et al. (2008) [59] found that consumers are largely aware of the high fat content of fast food, but generally appreciate its taste and convenience. They may thus experience an 
ambivalence toward fast food that reflects a trade-off in decision-making between short-term rewards (as captured by affective responses toward taste and convenience) and long-term costs (as reflected in understanding the cumulative health risk). How people resolve this ambivalence likely depends on the consideration they give to future consequences when making decisions [60]. Strathman et al. (1994) [61] argued that people who consider the future consequences of their behavior are more likely to forgo immediate reward, whereas those who show little concern for the longer-term effects of their behavior tend to have trouble delaying gratification [60]. Scholars have argued that an ability to foresee and value the future consequences of health-related behaviors likely plays a part in the formation of the related intention [62]. For many, eating fast food has a positive short-term consequence in terms of immediate satiation and hedonic pleasure [59], even though the long-term consequences of regularly eating energy-dense food are generally assumed to be negative.

Based on these findings, the following hypotheses are proposed:

Hypothesis 1. Food values are positively and significantly associated with hedonic benefits.

Hypothesis 2. Food values are positively and significantly associated with utilitarian benefits.

Hypothesis 3. Hedonic benefits related to food values are positively and significantly related to attitudes toward eating hamburgers.

Hypothesis 4. Utilitarian benefits related to food values are positively and significantly related to attitudes toward eating hamburgers.

Hypothesis 5. Attitude toward eating hamburgers is positively and significantly related to purchase intention.

In sum, this research tested five hypotheses inspired by the literature (illustrated in Figure 1).

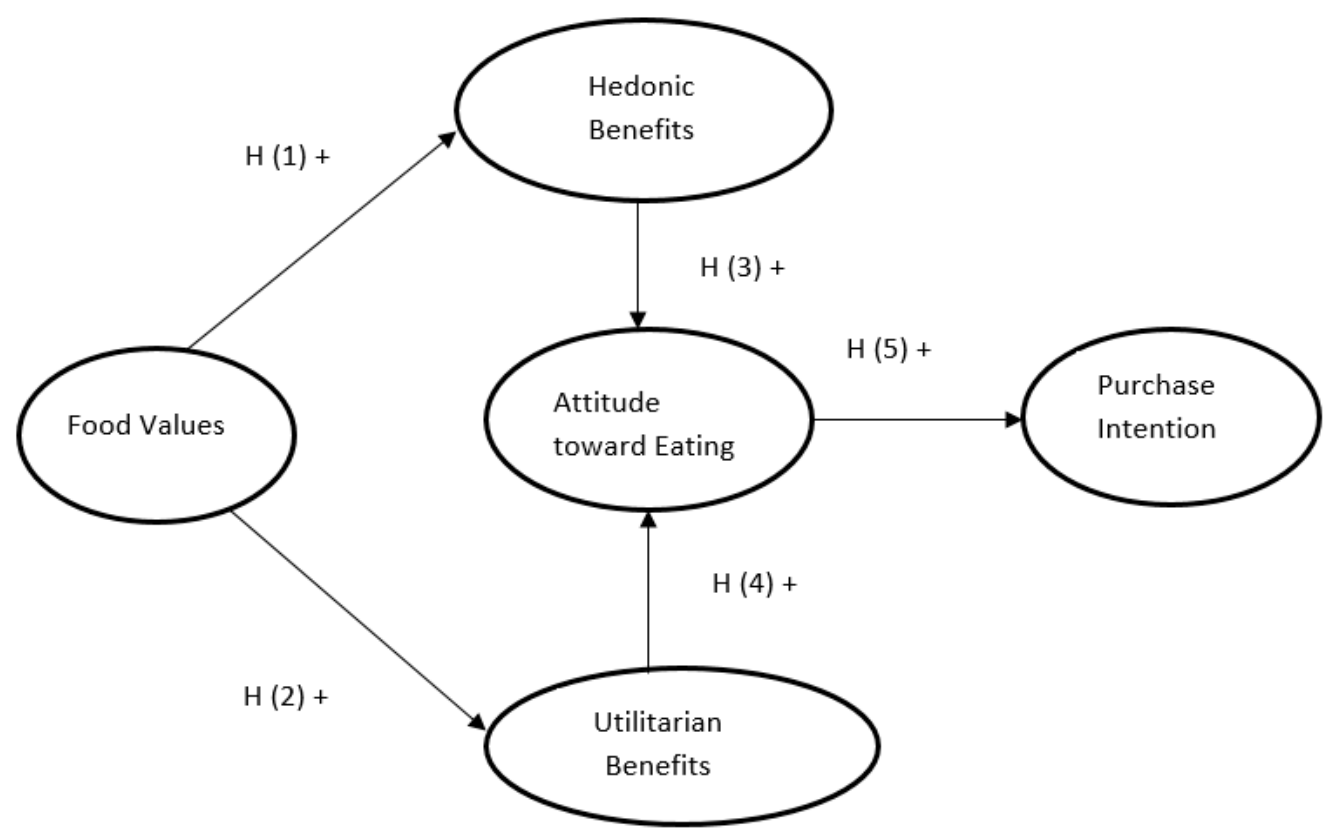

Figure 1. Model development.

\section{Materials and Methods}

In this section, we describe the empirical work and subsequent results. To test the model proposed in Figure 1, we designed a questionnaire intended to obtain information related to participants' socio-demographic profile and the study variables (food values, utilitarian benefits related to food 
values, hedonic benefits related to food values, attitudes toward eating hamburgers, and purchase intention). For the food-value variables, we adapted the scales of importance from Lusk and Briggeman (2009) [3] and Lusk (2011) [2]. These questions focused on the importance that respondents assigned to these corresponding values on a scale of 1 (least important) to 5 (most important) in relation to the main product offered by a hamburger fast-food restaurant, i.e., hamburgers. We also adapted the scale of 11 food values so that it referred to hedonic and utilitarian benefits. Participants rated these items on a five-point scale ( $1=$ least important; $5=$ most important). Regarding attitudes, we adapted scales from Haws and Winterich (2013) [48], and with regard to purchase intentions, we adapted scales from Chiu et al. (2012) [63] and Diallo (2012) [64], both of which employed a five-point scale (Table 1).

Table 1. Description of Variables.

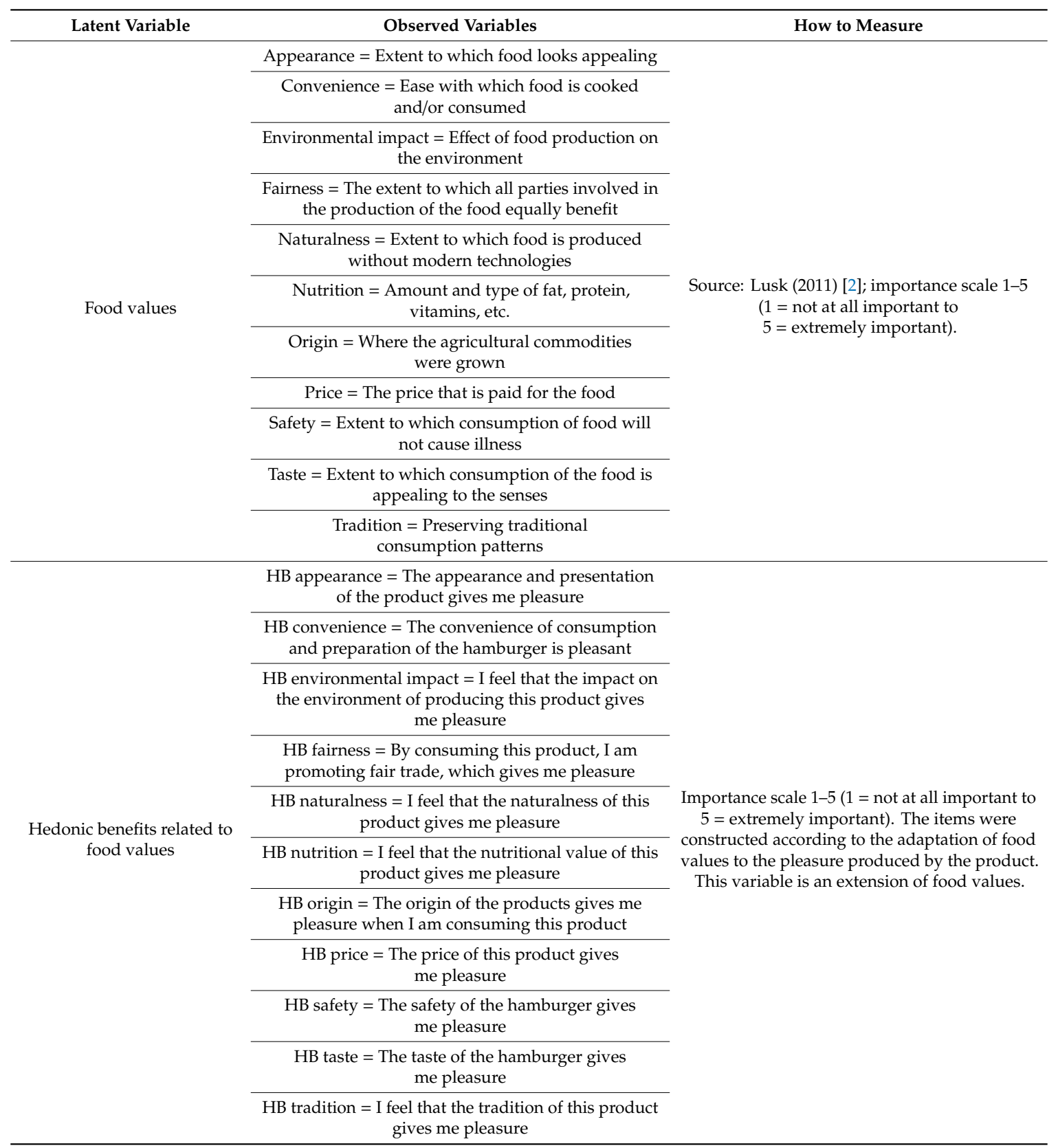


Table 1. Cont.

\begin{tabular}{|c|c|c|}
\hline Latent Variable & Observed Variables & How to Measure \\
\hline \multirow{8}{*}{$\begin{array}{l}\text { Utilitarian benefits related } \\
\text { to food values }\end{array}$} & $\begin{array}{l}\text { UB appearance }=\text { The appearance and presentation } \\
\text { of the product is useful and necessary }\end{array}$ & \multirow{8}{*}{$\begin{array}{l}\text { Importance scale } 1-5(1=\text { not at all important to } \\
5=\text { extremely important). The items were } \\
\text { constructed by adapting food values to } \\
\text { usefulness and consumer needs. This variable } \\
\text { is an extension of food values. }\end{array}$} \\
\hline & $\begin{array}{c}\text { UB environmental impact }=\mathrm{I} \text { feel that the impact on } \\
\text { the environment produced by food is useful } \\
\text { and necessary }\end{array}$ & \\
\hline & $\begin{array}{l}\text { UB fairness = By consuming this product, I am } \\
\text { promoting fair trade, which is useful and necessary }\end{array}$ & \\
\hline & $\begin{array}{l}\text { UB naturalness }=\text { The naturalness of the product } \\
\text { helps satisfy my hunger }\end{array}$ & \\
\hline & $\begin{array}{l}\text { UB nutrition = The nutrition obtained from eating a } \\
\text { hamburger is useful for what I need at a certain time }\end{array}$ & \\
\hline & $\begin{array}{c}\text { UB safety }=\text { The safety of the food helps me to satisfy } \\
\text { my need to eat }\end{array}$ & \\
\hline & $\begin{array}{l}\text { UB taste }=\text { I feel that the flavor helps satisfy } \\
\text { my hunger }\end{array}$ & \\
\hline & $\begin{array}{c}\text { UB tradition }=\text { I feel that tradition is useful } \\
\text { and necessary }\end{array}$ & \\
\hline \multirow{2}{*}{$\begin{array}{l}\text { Attitude toward eating } \\
\text { hamburgers }\end{array}$} & ATH1 = Eating a hamburger would be pleasurable & \multirow{2}{*}{$\begin{array}{l}\text { Adapted from Haws and Winterich (2013) [43]; } \\
\text { Likert scale } 1-5 \text { ( } 1=\text { strongly disagree to } \\
5=\text { strongly agree). }\end{array}$} \\
\hline & ATH2 = I would enjoy eating a hamburger & \\
\hline \multirow{2}{*}{ Purchase intention } & PI3 $=$ It is possible to buy a McDonald's product & \multirow{2}{*}{$\begin{array}{c}\text { Adapted from Chiu et al. (2012) [57]; } \\
\text { Diallo (2012) [58]; Likert scale 1-5 } \\
\text { (1 = strongly disagree to } 5=\text { strongly agree). }\end{array}$} \\
\hline & $\begin{array}{c}\text { PI }=\text { The probability that you would consider } \\
\text { buying a McDonald's product is high }\end{array}$ & \\
\hline
\end{tabular}

The questionnaire was originally written in English and then translated to Spanish by bilingual copyeditors specialized in the field of marketing. All the original items were then tested in a pretest with a sample of 20 consumers. The feedback obtained made it possible to identify some confusion surrounding certain items, especially with regard to the new constructs of the benefits. To address some critical issues related to the translation of the questionnaire, we sent the survey to two other experts. We were thus able to ensure the validity and functional interpretation of each item.

We distributed our survey among consumers in Puebla City, Mexico. We select the Puebla city because it is one of the most growing cities in México, with 1,576,259 persons ranked in the 4th with the national data [65]. Also, it necessary to mention that Puebla is considered one of the seven areas in Mexico with more concentration of food establishments [66].

Participation was voluntary, and in the end, 512 participants completed the questionnaire. The details are shown in Table 2. 
Table 2. Technical Details of the Research.

\begin{tabular}{cc}
\hline Universe & $\begin{array}{c}\text { Residents in the Metropolitan Area of } \\
\text { Puebla-Tlaxcala, Mexico }\end{array}$ \\
\hline Sample unit & People over 17 years old and buyers of fast food \\
\hline Data collection method & Personal survey \\
\hline Sample error & $9=\mathrm{q}=0.5 ; 5 \% \mathrm{~K}=2 ; \mathrm{e}= \pm 4.335$ \\
\hline Level of reliability & Probabilistic \\
\hline Sample procedure & 512 valid surveys \\
\hline Number surveyed & January 26-May 23 (2018) \\
\hline Period of information collection & McDonald's \\
\hline Fast-food restaurant &
\end{tabular}

\section{Empirical analysis}

Our participants were $58 \%$ female and $42 \%$ male. Almost $80 \%$ were $17-34$ years old, and about $70 \%$ were single. Moreover, $62.9 \%$ had bachelor's degrees, while $32.8 \%$ had a monthly income below 300 USD (See Table 3).

Table 3. Sociodemographic Profile.

\begin{tabular}{|c|c|c|c|c|c|}
\hline Variable & Items & $(\%)$ & Variable & Items & $(\%)$ \\
\hline \multirow{2}{*}{ Gender } & Male & 42 & \multirow{8}{*}{$\begin{array}{l}\text { Marital } \\
\text { status }\end{array}$} & Single & 69.9 \\
\hline & Female & 58 & & Married without children & 6.4 \\
\hline \multirow{7}{*}{ Age } & $17-24$ & 34 & & Married with children under 15 & 12.1 \\
\hline & $25-34$ & 44.5 & & Married with children over 16 & 6.8 \\
\hline & $35-44$ & 10.9 & & Divorced & 0.8 \\
\hline & $45-54$ & 5.7 & & Divorced with children under 15 & 1.4 \\
\hline & $55-64$ & 3.9 & & Divorced with children over 16 & 1.6 \\
\hline & $65-74$ & 0.6 & & Widowed & 1 \\
\hline & $75-84$ & 0.4 & \multirow{5}{*}{ Income } & Less than 300 USD & 32.8 \\
\hline \multirow{4}{*}{ Education level } & Less than high school & 5.1 & & 301-450 USD & 16.2 \\
\hline & High school & 16.6 & & 451-600 USD & 19.4 \\
\hline & Bachelor's degree & 62.9 & & 601-750 USD & 12.1 \\
\hline & Graduate/Master's degree & 15.4 & & more than 751 USD & 19.5 \\
\hline
\end{tabular}

The sample is mostly composed of younger consumers. We can infer that this particular fast-food has the primary market segment. Thus, these demographic results show the importance of analysis and considered appropriated the next outcomes.

We used PLS SEM (in conjunction with SmartPLS 3.2) to validate the model proposed in Figure 1. To establish the significance of the parameters, we performed bootstrapping with 10,000 resamples. To ensure construct reliability and validity, we first examined the indicator loadings for the reflective constructs. Those items with a loading of less than 0.7 were omitted (Hair et al., 2017) [67]. The 'food values' variable was considered a formative construct. The hedonic and utilitarian benefits items were adapted from the previous food values scale, and items with a loading of less than 0.7 were eliminated for these constructs as well. Unlike reflective indicators, formative indicators are not interchangeable; therefore, omitting a single indicator can reduce the validity of the measurement model's content [68].

In the next step, we evaluated construct reliability and validity. The most commonly used criterion is that proposed by Jöreskog (1971) [69], which establishes that values over 0.7 are considered good, and over 0.9 very good. We also calculated Cronbach's alpha, composite reliability, and average variance extracted (AVE). The Cronbach's alpha coefficient was acceptable, as all constructs achieved a coefficient 
greater than 0.7 [70]. Similarly, the AVE of each individual construct exceeded the acceptability value of 0.5 [71,72]. In fact, the composite reliability (CR) values were above 0.6 , indicating internal consistency reliability [67]. Likewise, the Rho A index for our variables was larger than 0.7 , indicating that they are homogenous [73] (Table 4).

Table 4. Construct Reliability and Validity.

\begin{tabular}{|c|c|c|c|c|c|c|c|c|}
\hline & ITEM & Average & $\begin{array}{l}\text { Standard } \\
\text { Deviation }\end{array}$ & Loading & Weights & $\begin{array}{c}\alpha \\
\text { Cronbach }\end{array}$ & CR & AVE \\
\hline \multirow{11}{*}{ FOOD VALUES } & Naturalness & 2.58 & 1.457 & & 0.152 & \multirow{11}{*}{ N.A. } & \multirow{11}{*}{ N.A } & \multirow{11}{*}{ N.A } \\
\hline & Taste & 3.71 & 1.259 & & 0.210 & & & \\
\hline & Price & 3.57 & 1.153 & & 0.060 & & & \\
\hline & Safety & 3.41 & 1.330 & & 0.179 & & & \\
\hline & Convenience & 3.60 & 1.207 & & 0.080 & & & \\
\hline & Nutrition & 2.41 & 1.307 & & 0.021 & & & \\
\hline & Tradition & 2.57 & 1.271 & & 0.177 & & & \\
\hline & Origin & 2.69 & 1.344 & & 0.115 & & & \\
\hline & Fairness & 2.65 & 1.305 & & 0.116 & & & \\
\hline & Appearance & 3.66 & 1.169 & & 0.272 & & & \\
\hline & $\begin{array}{l}\text { Environmental } \\
\text { impact }\end{array}$ & 2.91 & 1.289 & & 0.084 & & & \\
\hline \multirow{7}{*}{$\begin{array}{l}\text { HEDONIC } \\
\text { BENEFITS }\end{array}$} & HBnaturalness & 2.74 & 1.322 & 0.750 & & \multirow{7}{*}{0.870} & \multirow{7}{*}{0.900} & \multirow{7}{*}{0.562} \\
\hline & HBtaste & 3.47 & 1.260 & 0.775 & & & & \\
\hline & HBsafety & 2.92 & 1.234 & 0.773 & & & & \\
\hline & HBconvenience & 3.26 & 1.232 & 0.760 & & & & \\
\hline & HBtradition & 2.48 & 1.224 & 0.680 & & & & \\
\hline & HBorigin & 2.44 & 1.242 & 0.747 & & & & \\
\hline & HBappearance & 3.20 & 1.291 & 0.760 & & & & \\
\hline \multirow{8}{*}{$\begin{array}{l}\text { UTILITARIAN } \\
\text { BENEFITS }\end{array}$} & UBsafety & 2.97 & 1.178 & 0.733 & & \multirow{8}{*}{0.882} & \multirow{8}{*}{0.907} & \multirow{8}{*}{0.549} \\
\hline & UBconvenience & 3.22 & 1.190 & 0.675 & & & & \\
\hline & UBnutrition & 2.52 & 1.268 & 0.733 & & & & \\
\hline & UBtradition & 2.63 & 1.283 & 0.726 & & & & \\
\hline & UBorigin & 2.64 & 1.279 & 0.795 & & & & \\
\hline & UBfairness & 2.63 & 1.242 & 0.797 & & & & \\
\hline & UBappearance & 3.33 & 1.308 & 0.716 & & & & \\
\hline & UBenvironmental & 2.80 & 1.341 & 0.743 & & & & \\
\hline \multirow{4}{*}{ ATTITUDE } & ATH1 & 3.29 & 1.267 & 0.862 & & \multirow{4}{*}{0.847} & \multirow{4}{*}{0.897} & \multirow{4}{*}{0.687} \\
\hline & ATH2 & 2.88 & 1.252 & 0.780 & & & & \\
\hline & ATH3 & 3.08 & 1.262 & 0.895 & & & & \\
\hline & ATH4 & 3.70 & 1.321 & 0.773 & & & & \\
\hline \multirow{4}{*}{$\begin{array}{l}\text { PURCHASE } \\
\text { INTENTION }\end{array}$} & PI1 & 2.93 & 1.275 & 0.876 & & \multirow{4}{*}{0.902} & \multirow{4}{*}{0.932} & \multirow{4}{*}{0.774} \\
\hline & PI2 & 2.96 & 1.330 & 0.896 & & & & \\
\hline & PI3 & 3.26 & 1.219 & 0.904 & & & & \\
\hline & PI4 & 2.94 & 1.317 & 0.841 & & & & \\
\hline
\end{tabular}

Notes: N.A. = Not Applicable. Hedonic benefits eliminated: Price, Nutrition, Fairness, and Environmental impact.

Utilitarian benefits eliminated: Naturalness, Taste, and Price.

Afterward we examined discriminant validity, which is apparent if the correlation coefficient of two dimensions is less than the square root of the AVE [71] (See Table 5). 
Table 5. Discriminant Validity.

\begin{tabular}{cccccc}
\hline & Food Values & $\begin{array}{c}\text { Hedonic } \\
\text { Benefits }\end{array}$ & $\begin{array}{c}\text { Utilitarian } \\
\text { Benefits }\end{array}$ & Attitude & $\begin{array}{c}\text { Purchase } \\
\text { Intention }\end{array}$ \\
\hline Food values & N.A. & & & \\
\hline Hedonic benefits & 0.749 & 0.801 & & \\
\hline Utilitarian benefits & 0.651 & 0.724 & 0.741 & & \\
\hline Attitude & 0.366 & 0.464 & 0.425 & 0.829 & \\
\hline Purchase intention & 0.301 & 0.442 & 0.421 & 0.421 & 0.880 \\
\hline \multicolumn{7}{c}{ N.A. = Not Applicable } & &
\end{tabular}

After evaluating all the measurement instruments' psychometric properties, we estimated the model proposed in Figure 1. The estimated final model is shown in Table 6.

Table 6. Path Coefficients.

\begin{tabular}{ccccc}
\hline Hypothesis & Relationship & Beta & $t$-Value & $p$-Value \\
\hline H1 & Food values $\rightarrow$ Hedonic benefits & 0.749 & 32.41 & $0.000^{* * *}$ \\
\hline H2 & Food values $\rightarrow$ Utilitarian benefits & 0.651 & 20.039 & $0.001^{* * *}$ \\
\hline H3 & Hedonic benefits $\rightarrow$ Attitudes & 0.336 & 5.613 & $0.000^{* * *}$ \\
\hline H4 & Utilitarian benefits $\rightarrow$ Attitudes & 0.164 & 2.682 & $0.007^{* * *}$ \\
\hline H5 & Attitudes $\rightarrow$ Purchase intention & 0.535 & 14.686 & $0.000^{* * *}$ \\
\hline R2 Utilitarian Benefits $=0.424 ;$ R2 Hedonic Benefits $=0.562 ;$ R2 Attitude $=0.226 ;$ R2 Intention $=0.286$ Note: ${ }^{* * *} p \leq 0.01$.
\end{tabular}

Regarding the validity of all the constructs, Table 4 explains the factor loadings of indicators on the assigned construct, which needs to exceed the cut-off value of 0.7 [71]. Note that the PLS algorithm produces loadings (weights) between reflective (formative) constructs and their indicators.

\section{Discussion}

As can be seen in the descriptive analysis of the sample in Table 4, all the items used for the food values and hedonic and utilitarian benefits obtained above-average scores on the scale used. This analysis shows that, for food values, the highest-rated item was taste, while the lowest-rated item was nutrition. Furthermore, for hedonic benefits, the highest-rated item was taste, while for utilitarian benefits, the lowest-rated item was nutrition. These findings corroborate what many studies have already shown, namely, that this food product elicits some nutritional concerns (e.g., Mattsson and Helmersson, 2007) [56].

In addition, the top-rated items for the formative construct (food values) were, in descending order, appearance, taste, safety, and tradition $(0.272,0.210,0.179,0.177)$. In contrast, the lowest scores were given to nutrition, price, convenience and environmental impact $(0.021,0.060,0.080,0.084)$. For the hedonic benefits related to food values, the highest loadings were for taste, safety, appearance, and convenience $(0.775 ; 0.773 ; 0.760 ; 0.760)$. For the utilitarian benefits related to food values, the highest loadings were for fairness, origin, environmental impact, safety, and nutrition, the latter two benefits having the same loading $(0.797,0.795,0.743,0.733,0.733)$; in contrast, price was not a strong part of the construct. These findings evidence the crucial importance of safety, which is one of the most highly valued items not only in the food values construct, but also in the related hedonic and utilitarian benefits constructs. In other words, consumers give great importance to the certainty that consuming a hamburger at this kind of restaurant will not cause any illness, as well as to the hedonic and utilitarian benefits this value represents. This result is consistent with the literature review, where various studies [56-58] have found that consumers place high importance on health issues when consuming fast food. It is also worth highlighting that consumers assigned great importance to taste 
and appearance, since these items were also highly rated in both the food values construct and the related hedonic benefits construct. This is also consistent with findings previously reported elsewhere (e.g., Izquierdo-Yusta et al., 2019) [32].

As can be seen in Table 6, the support for all the hypotheses was confirmed through the path coefficients, standard error, $\mathrm{t}$ - value, and $p$-value. The most important effect was that of food values on hedonic benefits $(\mathrm{H} 1)\left(\beta=0.749 ; \rho=0.000^{* * *}\right)$. The relationship with the second-greatest weight was that postulated by $\mathrm{H} 2\left(\beta=0.651 ; \rho=0.001^{* * *}\right.$ ), highlighting the influence exerted by food values on utilitarian benefits. These findings show that food values have a higher impact on hedonic benefits than on utilitarian benefits. The third-most important relationship was the one posited by $\mathrm{H} 5$ ( $\beta=0.535$; $\left.\rho=0.000^{* * *}\right)$, confirming the importance of attitudes on intentions. This finding is consistent with previous research in the context of the TPB. The fourth-most important relationship was the influence of hedonic benefits on attitude captured by $\mathrm{H} 3\left(\beta=0.336 ; \rho=0.002^{* * *}\right)$. Finally, the least important effect was that posited by $\mathrm{H} 4$, i.e., the influence of utilitarian benefits on attitude $\left(\beta=0.164 ; \rho=0.007^{* * *}\right)$. Hedonic benefits thus had a greater impact on attitude than utilitarian ones, that is, although both types of benefits exerted an impact on attitude, the influence of hedonic benefits was greater.

\section{Conclusions}

Given the massive growth and success of the fast-food industry, scholars have been eager to analyze the strategies of the most important brands and translate those strategies to other sectors. This aligns with a desire among many companies not only to seek a larger market share and better consumer positioning, but also to adapt to changing consumer lifestyles and demographic patterns. On this basis, the present work analyzed consumers' decision-making process with regard to a specific type of fast food (hamburgers). Specifically, it examined the effects of: (i) Food values on their related benefits (hedonic and utilitarian); (ii) both kinds of benefits on people's attitudes toward eating hamburgers at fast-food restaurants; and (iii) attitudes on the intention to purchase such food.

One of the main conclusions that can be drawn from this research is that, in general, the food value items and both types of related benefits obtained above-average scores for the scale used. For food values, the most highly rated item was taste, while the lowest-rated item was nutrition. These findings are consistent with those obtained for benefits: While for hedonic benefits, the top-rated item was taste, for utilitarian benefits, the lowest-rated item was nutrition. These findings corroborate what many previous investigations have already shown, namely, that this is a product that elicits certain nutritional concerns. However, this food product might have an opportunity to build loyalty bonds with customers through the experiential aspects represented by taste. In addition, the importance of the item 'safety' should be highlighted, as it was one of the most highly rated items not only in the food values construct, but also in the related hedonic and utilitarian benefits constructs. This finding points to evidence of the health concerns that previous literature has also identified in relation to fast-food products.

We ultimately found support for all our proposed hypotheses. More specifically, we found that the strongest effect was that of the impact of food values on hedonic benefits, which was higher than that of food values on utilitarian benefits. In other words, food values are translated to a greater extent to hedonic benefits than utilitarian ones. We also observed an association between attitudes toward eating hamburgers and purchase intention, which is consistent with previous research. In addition, both hedonic and utilitarian benefits positively support the formation of positive attitudes toward hamburger consumption, at least for hamburgers sold by this fast-food chain. Although also confirmed, the weakest effects were those observed for the impact of utilitarian benefits on attitude, followed by the impact of hedonic benefits on attitude. This is clear evidence that the impact of hedonic benefits is relatively greater than that of utilitarian ones. Although there are more types of utilitarian benefits than hedonic ones, the importance of hedonic benefits lies in their consistency, as they explain food values better than utilitarian ones. 
This work makes several important contributions to the literature in this field. First, we have divided hedonic and utilitarian benefits based on the food values scales. Many of the items classified in these constructs had already been corroborated by previous research (e.g., taste for hedonic benefits), but others have been classified for the first time (e.g., environmental impact for utilitarian benefits). This latter finding is an important contribution for future research, since it is consistent with the demands of those new consumer segments who are concerned with environmental issues and identify to a greater extent with sustainability. In addition, our results align with prior research insofar as they stress the importance of hedonic and utilitarian benefits, with hedonic benefits being relatively more important.

In terms of managerial implications, the marketing campaigns of many organizations in the industry should incorporate a greater awareness of food values. Based on the importance they place on food safety, consumers seem to have settled on the idea that hamburgers may not be a very healthy food. In the long term, these companies should thus adjust their advertising messages to emphasize healthier values. Additionally, they should make strategic changes to address the low score given to nutrition: Their communication should focus on changing this perception of the product in consumers' minds. Such changes should be made given that new consumer segments are more informed, value eating healthy products, look at nutritional information, and, consequently, may be willing to pay a premium price to satisfy their preferences. Specially, we found a significant number of younger consumers in this sample. In that sense, fast-food restaurants need to apply research to get more information about the new communication patterns and the impact on consumer behavior in this market segment. Social media, influencers, promotions, and other elements have to see if there is a relationship with these first data.

The strength of this study is limited by the questionable comparability of the chosen sample. To include consumers with different ages, education level, marital status and income, it can be a limitation of this study. Besides, some products exist that own nature considers as a healthier option as yogurt, milk, chia seeds, fruits, vegetables, organic ingredients, and fiber, among others [74-76]. Correspondingly, the quantity and variety of foods could be difference in some segments analyzed [77]. Future research should thus include comparative studies of different samples, fast-food chains, and fast-food products. This would afford a better understanding of this research line.

Author Contributions: Conceptualization, H.H.P.-V. and M.P.M.-R.; methodology, H.H.P.-V., A.I.-Y., and C.M.G.-C.; software, H.H.P.-V. and A.I.-Y.; validation, H.H.P.-V., A.I.-Y., and C.M.G.-C.; formal analysis, H.H.P.-V., M.P.M.-R., A.I.-Y., and C.M.G.-C.; investigation, H.H.P.-V.; resources; H.H.P.-V.; data curation, A.I.-Y. and C.M.G.-C.; writing—original draft preparation, H.H.P.-V., M.P.M.-R., A.I.-Y., and C.M.G.-C.; writing—review and editing, H.H.P.-V., M.P.M.-R., A.I.-Y., and C.M.G.-C.; visualization, H.H.P.-V. and C.M.G.-C.; supervision, M.P.M.-R. and A.I.-Y.; project administration, H.H.P.-V.; funding acquisition, M.P.M.-R. and C.M.G.-C. All authors have read and agreed to the published version of the manuscript.

Funding: This research was funded by the University of Castilla-La Mancha. Group “Observatorio de la Innovación en Distribución Comercial".

Conflicts of Interest: The authors declare no conflict of interest.

\section{References}

1. Barahona:, I.; Hernández, D.M.; Pérez-Villarreal, H.H.; del Pilar Martínez-Ruíz, M. Identifying research topics in marketing science along the past decade: A content analysis. Scientometrics 2018, 117, $293-312$. [CrossRef]

2. Lusk, J.L. External validity of the food values scale. Food Qual. Prefer. 2011, 22, 452-462. [CrossRef]

3. Lusk, J.L.; Briggeman, B.C. Food Values. Am. J. Agric. Econ. 2009, 91, 184-196. [CrossRef]

4. Martínez-Ruiz, M.P.; Gómez-Cantó, C.M. Key External Influences Affecting Consumers' Decisions Regarding Food. Front. Psychol. 2016, 7, 1618. [CrossRef] [PubMed]

5. Enneking, U.; Neumann, C.; Henneberg, S. How important intrinsic and extrinsic product attributes affect purchase decision. Food Qual. Prefer. 2007, 18, 133-138. [CrossRef] 
6. Estiri, M.; Hasangholi, T.; Yazdani, H.; Nejad, H.J.; Rayej, H. Food Products Consumer Behaviors: The Role of Packaging Elements. J. Appl. Sci. 2010, 10, 535-543. [CrossRef]

7. Grunert, K.G. Cómo los cambios en el comportamiento del consumidor y la distribuciónafectan a la competencia de los productores y procesadores de alimentos. Econ. Agrar. Recur. Nat. 2011, 6, 3. [CrossRef]

8. Grunert, K.G. How changes in consumer behaviour and retailing affect competence requirements for food producers and processors. Econ. Agrar. y Recur. Nat. 2006, 6, 3-22.

9. Lister, G.; Tonsor, G.T.; Brix, M.; Schroeder, T.C.; Yang, C. Food Values Applied to Livestock Products. J. Food Prod. Mark. 2017, 23, 326-341. [CrossRef]

10. Bloch, P.H. The product enthusiast: Implications for marketing strategy. J. Consum. Mark. 1986, 3, 51-62. [CrossRef]

11. Otnes, C.; Ruth, J.; Crosby, E.M. Product-agency benefits: Consumer perspectives and strategic implications. Eur. J. Mark. 2014, 48, 878-898. [CrossRef]

12. Ghosh Chowdhury, T.; Murshed, F.; Khare, A. Flexible flexibility! Food categorization flexibility and utilitarian preference. J. Consum. Mark. 2018, 35, 1-10. [CrossRef]

13. Chitturi, R.; Raghunathan, R.; Mahajan, V. Delight by Design: The Role of Hedonic Versus Utilitarian Benefits. J. Mark. 2008, 72, 48-63. [CrossRef]

14. Crowley, A.E.; Spangenberg, E.R.; Hughes, K.R. Measuring the hedonic and utilitarian dimensions of attitudes toward product categories. Mark. Lett. 1992, 3, 239-249. [CrossRef]

15. Mowen, J.C.; Minor, M. Consumer Behavior, 5th ed.; Prentice-Hall: Upper Saddle River, NJ, USA, 1998.

16. Verbeke, W.; Viaene, J. Beliefs, attitude and behaviour towards fresh meat consumption in Belgium: Empirical evidence from a consumer survey. Food Qual. Prefer. 1999, 10, 437-445. [CrossRef]

17. Fishbein, M.; Ajzen, I. Belief, Attitude, Intention, and Behavior: An Introduction to Theory and Research; AddisonWesley Series in Social Psychology; Addison-Wesley Pub. Co.: Boston, MA, USA, 1975.

18. Tuu, H.H.; Olsen, S.O.; Thao, D.T.; Anh, N.T.K. The role of norms in explaining attitudes, intention and consumption of a common food (fish) in Vietnam. Appetite. 2008, 51, 546-551. [CrossRef] [PubMed]

19. Shepherd, R. Factors influencing food preferences and choice. In Handbook of the Psychophysiology of Human Eating; Shepherd, R., Ed.; John Wiley \& Sons Ltd.: Chichester, UK, 1989.

20. Ajzen, I. The theory of planned behavior. Organ. Behav. Hum. Decis. Process. 1991, 50, 179-211. [CrossRef]

21. Louis, W.; Davies, S.; Smith, J.; Terry, D. Pizza and Pop and the Student Identity: The Role of Referent Group Norms in Healthy and Unhealthy Eating. J. Soc. Psychol. 2007, 147, 57-74. [CrossRef]

22. Eagly, A.H.; Chaiken, S. The Psychology of Attitudes; Harcourt Brace Jovanovich College Publishers: Fort Worth, TX, USA, 1993.

23. Armitage, C.J.; Conner, M. Efficacy of the Theory of Planned Behaviour: A meta-analytic review. Br. J. Soc. Psychol. 2001, 40, 471-499. [CrossRef]

24. Conner, M.; Armitage, C.J. Extending the Theory of Planned Behavior: A Review and Avenues for Further Research. J. Appl. Soc. Psychol. 1998, 28, 1429-1464. [CrossRef]

25. Pérez-Villarreal, H.H.; Martínez-Ruiz, M.P.; Izquierdo-Yusta, A. Testing Model of Purchase Intention for Fast Food in Mexico: How do Consumers React to Food Values, Positive Anticipated Emotions, Attitude toward the Brand, and Attitude toward Eating Hamburgers? Foods. 2019, 8, 369. [CrossRef] [PubMed]

26. Gallegos-Hernández, B.P.; Pérez-Villarreal, H.H.; Barahona, I.; Mayett-Moreno, Y. Analysis of the intrinsic signals, extrinsic signals and the expected quality of the organic tortilla to assess its purchasing intentions. Cogent Bus. Manag. 2018, 5, 1548548. [CrossRef]

27. Hong, L.; Yao, L.; Xie, P.; Li, W. An empirical study on consumer purchase intention for nuts and influencing factors-Survey based on consumers from Zhejiang. Food Control. 2020, 117, 107343. [CrossRef]

28. Bazzani, C.; Gustavsen, G.W.; Nayga, R.M.; Rickertsen, K. A comparative study of food values between the United States and Norway. Eur. Rev. Agric. Econ. 2018, 45, 239-272. [CrossRef]

29. Izquierdo-Yusta, A.; Gómez-Cantó, C.M.; Martínez-Ruiz, M.P.; Pérez-Villarreal, H.H. The influence of food values on post-purchase variables at food establishments. Br. Food J. 2020, 122, 2061-2076. [CrossRef]

30. Yang, Y.; Hobbs, J.E. Food Values and Heterogeneous Consumer Responses to Nanotechnology. Available online: https://onlinelibrary.wiley.com/doi/abs/10.1111/cjag.12225 (accessed on 21 April 2020).

31. Arena, E.; Mazzaglia, A.; Selvaggi, R.; Pecorino, B.; Fallico, B.; Serranò, M.; Pappalardo, G. Exploring Consumer's Propensity to Consume Insect-Based Foods. Empirical Evidence from a Study in Southern Italy. Appl. Syst. Innov. 2020, 3, 38. [CrossRef] 
32. Izquierdo-Yusta, A.; Gómez-Cantó, C.M.; Pelegrin-Borondo, J.; Martínez-Ruiz, M.P. Consumers' behaviour in fast-food restaurants: A food value perspective from Spain. Br. Food J. 2019, 121, 386-399. [CrossRef]

33. Batra, R.; Ahtola, O.T. Measuring the hedonic and utilitarian sources of consumer attitudes. Mark. Lett. 1991, 2, 159-170. [CrossRef]

34. Dhar, R.; Wertenbroch, K. Consumer Choice between Hedonic and Utilitarian Goods. J. Mark. Res. 2000, 37, 60-71. [CrossRef]

35. Voss, K.E.; Spangenberg, E.R.; Grohmann, B. Measuring the Hedonic and Utilitarian Dimensions of Consumer Attitude. J. Mark. Res. 2003, 40, 310-320. [CrossRef]

36. Babin, B.J.; Darden, W.R.; Griffin, M. Work and/or Fun: Measuring Hedonic and Utilitarian Shopping Value. J. Consum. Res. 1994, 20, 644. [CrossRef]

37. Cramer, L.; Antonides, G. Endowment effects for hedonic and utilitarian food products. Food Qual. Prefer. 2011, 22, 3-10. [CrossRef]

38. Khongrangjem, T.; Dsouza, S.M.; Prabhu, P.; Dhange, V.B.; Pari, V.; Ahirwar, S.K.; Sumit, K. A study to assess the knowledge and practice of fast food consumption among Pre-University students in Udupi Taluk, Karnataka, India. Clin. Epidemiol. Glob. Health 2018, 6, 172-175. [CrossRef]

39. Loebnitz, N.; Grunert, K.G. Impact of self-health awareness and perceived product benefits on purchase intentions for hedonic and utilitarian foods with nutrition claims. Food Qual. Prefer. 2018, 64, 221-231. [CrossRef]

40. Maehle, N.; Iversen, N.; Hem, L.; Otnes, C. Exploring consumer preferences for hedonic and utilitarian food attributes. Br. Food J. 2015, 117, 3039-3063. [CrossRef]

41. Wakefield, K.L.; Inman, J.J. Situational price sensitivity: The role of consumption occasion, social context and income. J. Retail. 2003, 79, 199-212. [CrossRef]

42. Liu, R.; Gao, Z.; Snell, H.A.; Ma, H. Food safety concerns and consumer preferences for food safety attributes: Evidence from China. Food Control. 2020, 112, 107157. [CrossRef]

43. Bredahl, L. Determinants of Consumer Attitudes and Purchase Intentions With Regard to Genetically Modified Food-Results of a Cross-National Survey. J. Consum. Policy 2001, 24, 23-61. [CrossRef]

44. Bonne, K.; Vermeir, I.; Verbeke, W. Impact of Religion on Halal Meat Consumption Decision Making in Belgium. J. Int. Food Agribus. Mark. 2008, 21, 5-26. [CrossRef]

45. Saba, A.; Di Natale, R. Attitudes, intention and habit: Their role in predicting actual consumption of fats and oils. J. Hum. Nutr. Diet. 1998, 11, 21-32. [CrossRef]

46. Ajzen, I.; Fishbein, M. Understanding Attitudes and Predicting Social Behavior; Prentice-Hall: Englewood Cliffs, NJ, USA, 1980.

47. Mowen, J.C. Consumer Behavior, 3rd ed.; The Macmillan series in marketing; Maxwell Macmillan Canada: Toronto, ON, Canada, 1993.

48. Haws, K.L.; Winterich, K.P. When Value Trumps Health in a Supersized World. J. Mark. 2013, 77, 48-64. [CrossRef]

49. Zhang, Y.; Jing, L.; Bai, Q.; Shao, W.; Feng, Y.; Yin, S.; Zhang, M. Application of an integrated framework to examine Chinese consumers' purchase intention toward genetically modified food. Food Qual. Prefer. 2018, 65, 118-128. [CrossRef]

50. Chen, M. Attitude toward organic foods among Taiwanese as related to health consciousness, environmental attitudes, and the mediating effects of a healthy lifestyle. Br. Food J. 2009, 111, 165-178. [CrossRef]

51. Vaz, T.d.N.; Nijkamp, P.; Rastoin, J.-L. Traditional Food Production and Rural Sustainable Development a European Challenge; Ashgate: Farnham, UK, 2009.

52. Chan, K.; Tsang, L. Promote healthy eating among adolescents: A Hong Kong study. J. Consum. Mark. 2011, 28, 354-362. [CrossRef]

53. Close, M.A.; Lytle, L.A.; Chen, D.-G.; Viera, A.J. Using the theory of planned behavior to explain intention to eat a healthful diet among Southeastern United States office workers. Nutr. Food Sci. 2018, 48, 365-374. [CrossRef]

54. Luomala, H.; Jokitalo, M.; Karhu, H.; Hietaranta-Luoma, H.-L.; Hopia, A.; Hietamäki, S. Perceived health and taste ambivalence in food consumption. J. Consum. Mark. 2015, 32, 290-301. [CrossRef]

55. Nystrand, B.T.; Olsen, S.O. Consumers' attitudes and intentions toward consuming functional foods in Norway. Food Qual. Prefer. 2020, 80, 103827. [CrossRef] 
56. Mattsson, J.; Helmersson, H. Eating fast food: Attitudes of high-school students. Int. J. Consum. Stud. 2007, 31, 117-121. [CrossRef]

57. Yoon, B.; Chung, Y. Consumer Attitude and Visit Intention toward Food-Trucks: Targeting Millennials. J. Foodserv. Bus. Res. 2018, 21, 187-199. [CrossRef]

58. Ghoochani, O.M.; Torabi, R.; Hojjati, M.; Ghanian, M.; Kitterlin, M. Factors influencing Iranian consumers' attitudes toward fast-food consumption. Br. Food J. 2018, 120, 409-423. [CrossRef]

59. Dunn, K.I.; Mohr, P.B.; Wilson, C.J.; Wittert, G.A. Beliefs about fast food in Australia: A qualitative analysis. Appetite 2008, 51, 331-334. [CrossRef] [PubMed]

60. Dunn, K.I.; Mohr, P.; Wilson, C.J.; Wittert, G.A. Determinants of fast-food consumption. An application of the Theory of Planned Behaviour. Appetite 2011, 57, 349-357. [CrossRef] [PubMed]

61. Strathman, A.; Gleicher, F.; Boninger, D.S.; Edwards, C.S. The consideration of future consequences: Weighing immediate and distant outcomes of behavior. J. Pers. Soc. Psychol. 1994, 66, 742-752. [CrossRef]

62. Sirois, F.M. Procrastination and intentions to perform health behaviors: The role of self-efficacy and the consideration of future consequences. Personal. Individ. Differ. 2004, 37, 115-128. [CrossRef]

63. Chiu, H.-C.; Hsieh, Y.-C.; Kuo, Y.-C. How to Align your Brand Stories with Your Products. J. Retail. 2012, 88, 262-275. [CrossRef]

64. Diallo, M.F. Effects of store image and store brand price-image on store brand purchase intention: Application to an emerging market. J. Retail. Consum. Serv. 2012, 19, 360-367. [CrossRef]

65. Encuesta Intercensal 2015; Instituto Nacional de Estadística y Geografía: DF, México, 2015.

66. Datos de la Industria: Cifras de la Industria Restaurantera; Asociación Mexicana de Restaurantes: CDMX, México, 2019.

67. Hair, J.; Hollingsworth, C.L.; Randolph, A.B.; Chong, A.Y.L. An updated and expanded assessment of PLS-SEM in information systems research. Ind. Manag. Data Syst. 2017, 117, 442-458. [CrossRef]

68. Diamantopoulos, A.; Papadopoulos, N. Assessing the cross-national invariance of formative measures: Guidelines for international business researchers. J. Int. Bus. Stud. 2010, 41, 360-370. [CrossRef]

69. Jöreskog, K.G. Statistical analysis of sets of congeneric tests. Psychometrika. 1971, 36, 109-133. [CrossRef]

70. Hair, J.F.; Black, W.; Babin, B.J.; Anderson, R.E. Multivariate Data Analysis: A Global Perspective, 7th ed.; Pearson: Upper Saddle River, NJ, USA, 2010.

71. Fornell, C.; Larcker, D.F. Evaluating Structural Equation Models with Unobservable Variables and Measurement Error. J. Mark. Res. 1981, 18, 39. [CrossRef]

72. Huang, C.-C.; Wang, Y.-M.; Wu, T.-W.; Wang, P.-A. An Empirical Analysis of the Antecedents and Performance Consequences of Using the Moodle Platform. Int. J. Inf. Educ. Technol. 2013, 3, 217-221. [CrossRef]

73. Werts, C.E.; Linn, R.L.; Jöreskog, K.G. Intraclass Reliability Estimates: Testing Structural Assumptions. Educ. Psychol. Meas. 1974, 34, 25-33. [CrossRef]

74. Kowaleski, J.; Quast, L.B.; Steffens, J.; Lovato, F.; Rodrigues dos Santos, L.; Zambiazi da Silva, S.; Maschio de Souza, D.; Felicetti, M.A. Functional yogurt with strawberries and chia seeds. Food Biosci. 2020, 37, 100726. [CrossRef]

75. Harwood, W.S.; Drake, M.A. Identification and characterization of fluid milk consumer groups. J. Dairy Sci. 2018, 101, 8860-8874. [CrossRef] [PubMed]

76. Hanson, N.; Yun, W. Should "big food" companies introduce healthier options? The effect of new product announcements on shareholder value. Mark. Lett. 2018, 29, 1-12. [CrossRef]

77. Vega-Zamora, M.; Parras-Rosa, M.; Torres-Ruiz, F.J. You Are What You Eat: The Relationship between Values and Organic Food Consumption. Sustainability. 2020, 12, 3900. [CrossRef]

(C) 2020 by the authors. Licensee MDPI, Basel, Switzerland. This article is an open access article distributed under the terms and conditions of the Creative Commons Attribution (CC BY) license (http://creativecommons.org/licenses/by/4.0/). 